\title{
Community structure and diversity of demersal fish assemblages: the role of fishery*
}

\author{
MARY LABROPOULOU and COSTAS PAPACONSTANTINOU
}

National Centre for Marine Research, Agios Kosmas, Hellinikon, 16604 Athens, Greece. E-mail: mlabro@ncmr.gr

\begin{abstract}
SUMMARY: Seasonal experimental trawl surveys were carried out in the Northern Aegean and Thracian seas (NE Mediterranean, Greece), from summer 1990 to autumn 1993, during which a total of 172 fish species were caught. In these areas, fishing pressure is very high, since approximately $50 \%$ of the Greek otter trawl fleet operates there, producing more than $57 \%$ of the total demersal landings. Different statistics were used to assess spatial structure, seasonal changes and diversity of the demersal fish assemblages on the continental shelf and upper slope. The following measures were applied to the species abundance matrix: species diversity, species richness, evenness and dominance. The analysis of 501 bottom trawls revealed that, in general, species diversity, richness and evenness decreased with water depth, with the highest values at depths $<100 \mathrm{~m}$, whereas dominance increased with depth, with its maximum at depths $>200 \mathrm{~m}$. The effect of depth on the diversity patterns observed was always significant, while seasonal trends were similar with those described for the overall diversity characteristics in each area. Classification and ordination methods showed the existence of 4 groups associated with the continental shelf and upper slope in each area. Classification of the top ranking species at each group and area revealed that commercially important species were dominant in the shallowest zone $(<30 \mathrm{~m})$, while non-commercial species predominated at depths below $200 \mathrm{~m}$. At intermediate depths $(30-200 \mathrm{~m})$ almost $50 \%$ of the total catches were composed of non-commercially important fish species. However, since most species had a wide distribution range these differences were rather quantitative than qualitative. The results indicated that although spatial changes in abundance could be detected, temporal changes were not obvious. Environmental variability and overexploitation, as well as differences in species' life-history strategies, have both influenced the structure of the demersal fish assemblages found along the depth gradient studied.
\end{abstract}

Key words: demersal fish, community structure, diversity, dominance, fishing effects, North Eastern Mediterranean

RESUMEN: ESTRUCTURA Y DIVERSIDAD DE LAS ASOCIACIONES DE PECES DEMERSALES: EL PAPEL DE LA PESQUERÍA. - Se realizaron pescas de arrastre experimentales en los mares Egeo septentrional y de Tracia (NE Mediterráneo, Grecia) desde el verano de 1990 al otoño de 1993, durante las cuales se capturó un total de 172 especies de peces. En estas áreas, la presión pesquera es muy elevada, puesto que aproximadamente el $50 \%$ de la flota griega de arrastre con puertas faena allí, produciendo más del 57\% del total de desembarcos de especies demersales. Se utilizaron diferentes estadísticos para evaluar la estructura espacial, los cambios estacionales y la diversidad de las asociaciones de peces demersales en la plataforma continental y parte superior del talud. Se estimaron los siguientes parámetros a partir de la matriz de abundancia específica: diversidad específica, riqueza específica, uniformidad y dominancia. El análisis de 501 pescas de arrastre reveló que, en general, la diversidad específica, la uniformidad y la dominancia decrecían con la profundidad del agua, con valores máximos a profundidades $<100 \mathrm{~m}$, mientras que la dominancia aumentó con la profundidad, con máximos a profundidades $>200$ $\mathrm{m}$. El efecto de la profundidad en las pautas de diversidad observadas fue siempre significativo, mientras que las tendencias estacionales fueron similares a las descritas para todas las características de la diversidad en cada área. Los métodos de clasificación y ordenación mostraron la existencia de 4 grupos asociados con la plataforma continental y parte superior del talud de cada área. La clasificación de las primeras especies por abundancia en cada grupo y área reveló que las especies importantes desde el punto de vista comercial eran dominantes en la zona más somera $(<30 \mathrm{~m})$, mientras que las especies no comerciales predominaron en profundidades por debajo de $200 \mathrm{~m}$. En profundidades intermedias (30-200 m), casi el $50 \%$ del total de las capturas comprendía especies de peces no importantes desde el punto de vista comercial. Sin embargo, como la mayoría de especies tenían un amplio rango de distribución, estas diferencias fueron más cuantitativas que cualitativas. Los resultados indicaron que aunque podían detectarse cambios espaciales en la abundancia, los cambios temporales no eran 
evidentes. La variabilidad ambiental y la sobreexplotación, así como diferencias en las estrategias ecológicas de las especies, han influido en la estructura de las asociaciones de peces demersales que se encuentran a lo largo del gradiente de profundidad estudiado.

Palabras clave: peces demersales, estructura de la comunidad, diversidad, dominancia, efectos de la pesca, Mediterráneo nororiental.

\section{INTRODUCTION}

Information on soft-bottom fish assemblages is particularly scarce in the Eastern Mediterranean region where demersal fish are heavily exploited as principal targets or as by-catch. In Greek waters demersal fishes of the continental shelf and slope are subjected to an intensive fishery carried out by trawl, gillnet and longline fleets. The gillnets and longlines catch a small number of species, whereas the trawl fleet exploits a multi-species fishery targeting several demersal and benthic species. The results of experimental trawl fishing in the Greek seas indicated that commercially important demersal and inshore stocks suffer from gross overfishing. As a result, commercial catches consist mainly of young immature individuals and a variety of non-commercial species that are discarded.

Changes in species composition with depth on continental shelf and slope have been well established for many areas (e.g. Haedrich et al., 1980; Carney et al., 1983; Abelló et al., 1988; Hecker, 1990; Cartes and Sardá, 1993; Koslow, 1993; Smale et al., 1993; Cartes et al., 1994; Sardá et al., 1994; Gordon et al., 1995; Fariña et al., 1997a). Both physical and biological factors have been discussed as causes of faunal zonation with depth. Hydrographic conditions, the steepness of the continental slope, and substrate type are among the major physical factors considered. Resource availability, predator-prey relationships and interspecific competition are the most important biological factors reported. Most studies have examined megafaunal assemblages, while, only recently, studies of fish community structure have focused on patterns of spatial and temporal variation in composition, abundance and distribution of demersal fish assemblages of the continental shelf and slope at several latitudes (Markle et al., 1988; Bianchi, 1991, 1992a, 1992b; Fujita et al., 1995; Fariña et al., 1997b; García et al., 1998; Moranta et al., 1998; Labropoulou and Papaconstantinou, 2000). Recent work has demonstrated changes in species composition and size structure of demersal fish communities in response to fishing (Haedrich and Barnes, 1997; Sainsbury et al., 1997;
Zwanenburg, 2000). It appears that a key challenge is to incorporate ecosystem objectives within fisheries management including measurable indicators such as ecosystem diversity, species diversity and ecologically depended species (Gislason et al., 2000).

In the present study, trawl catch data obtained seasonally, in 3 successive years (summer 1990autumn 1993) from the north Aegean Sea, that has historically been at the highest levels of fishing pressure in the NE Mediterranean, were analysed to investigate the structure of the demersal fish community. Comparison of assemblages from similar ecosystems in different areas might reveal general trends in the community dynamics of the Mediterranean.

\section{MATERIAL AND METHODS}

\section{Study area and sampling procedure}

The North Aegean Sea is an almost rectangular basin, separated from the South Aegean by the Cyclades islands archipelago, and is typically an oligotrophic sea. However, almost $70 \%$ of the total Greek catches are derived from the North Aegean Sea, due to intense exploitation by different fishing gears: pelagic and bottom trawls, purse-seines and nets (Papaconstantinou and Farrugio, 2000). Approximately $50 \%$ of the Greek otter trawl fleet operates in the North Aegean sea (Northern Aegean and Thracian seas), producing more than $57 \%$ of the total demersal landings (NSSG 1990-1999).

A total of 501 hauls were taken during sixteen experimental bottom trawl survey cruises on a seasonal basis from standard depth stations between 16$500 \mathrm{~m}$ (Fig. 1). Specifically, 215 hauls were taken in the Northern Aegean Sea between summer 1990 and spring 1992 and 286 in the Thracian Sea from fall 1991 to winter 1993. Sampling stations were selected randomly with depth-stratification. The otter trawl used (foot-rope length: $65.7 \mathrm{~m}$, headline height: $1.5 \mathrm{~m}$ ) was equipped with a cod-end bag liner of $16 \mathrm{~mm}$ stretched mesh. Samples were col- 


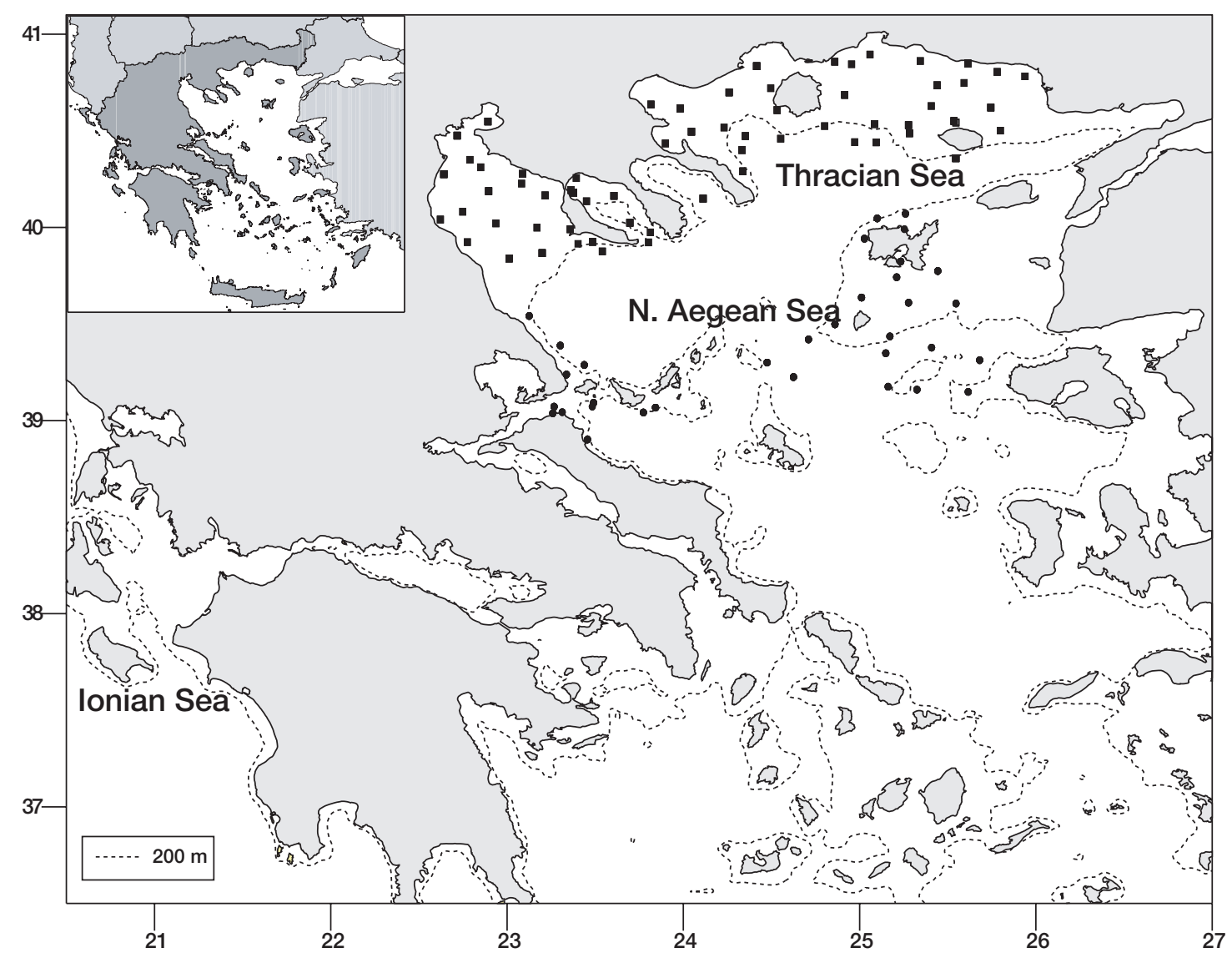

Fig. 1. - Sampling stations on the continental shelf and the upper slope of the study area. Full squares, Thracian sea; full circles, Northern Aegean sea.

lected during daylight between 0800 and 1700 hours. The duration of each trawl (bottom time) was 30-60 min and the trawling speed fluctuated from 2.5 to 3.0 knots depending on the depth and the nature of the substrate. The catch from each haul was sorted and identified to species level, and each species was enumerated and weighed separately on board. A part of the catch was frozen or preserved in formalin for later study. Since all hauls were carried out using a commercial trawl vessel and the same fishing gear it was assumed that gear selectivity was constant.

\section{Data analysis}

Species abundances were calculated for each haul after standardization of the data to a 1-hour tow, making it possible to allow comparisons between sampling stations. Those species regarded as markedly pelagic in behaviour were excluded from the analyses, since they had not been quantitatively sampled. To identify zonation patterns cluster analysis was applied to the species abundance matrix.
Cluster analysis (group average), employing the Bray-Curtis similarity index (Field et al., 1982), was applied to the standardized abundance values of the species using the PRIMER algorithms (Plymouth Marine Laboratory). In order to normalize the data and avoid skew, a square root transformation was applied to the abundance data prior to cluster analysis (Field et al., 1982). Multidimensional scaling (MDS) ordination analysis was also performed with the same configuration as in cluster analysis with respect to similarity index and transformation. The typifying and discriminating species of the cluster of stations were determined using the SIMPER procedure (Clarke, 1993). This procedure indicates the average contribution (\% Cum.) of each species to the similarity (typifying species) and dissimilarity (discriminating species) between groups of samples. Variation in species relative abundance was also examined by using the graphical representations of species cumulative frequency distributions ( $k$-dominance curves, Lambshead et al., 1983). Relative abundance of demersal species was superimposed using the ABC method of Warwick (1986) to pro- 
vide information on the size of the most dominant species.

The ecological parameters of abundance, number of species $(S)$, species diversity, Shannon-Wiener index (Hurlbert, 1978):

$$
H^{\prime}=-\sum_{i=1}^{S} p_{i} \log _{2} p_{i}
$$

species richness (Margalef, 1968):

$$
d=\frac{(s-1)}{\log \mathrm{N}}
$$

evenness (Pielou 1966):

$$
\mathrm{J}=\frac{\mathrm{H}^{\prime}}{\mathrm{H}_{\max }}
$$

and dominance, Simpson's index (Krebs 1989):

$$
\mathrm{D}=\sum p_{i}^{2}
$$

were calculated for each of the station-groups defined by cluster analysis, where $p_{i}=$ proportion of total sample belonging to $i$ th species, $\mathrm{N}=$ the number of individuals of the entire sample and $\mathrm{H}_{\max }=$ $\log (S)$. Furthermore, analysis of variance was used to determine how these attributes changed with water depth, and the a posteriori Tukey's test was employed to locate the source of any differences. Before using parametric tests, the assumptions of normality and homoscedasticity were tested and when these assumptions failed, the data were log $(\mathrm{x}+1)$-transformed (Sokal and Rohlf, 1981; Zar, 1984). All statistical inferences were based on the 0.05 significance level.

\section{RESULTS}

\section{Overall catch}

A total of 172 demersal fish species belonging to 61 families were collected from 501 trawls. In the Northern Aegean Sea, 136 species were found over the continental shelf $(<200 \mathrm{~m})$, while the upper slope assemblage consisted of 109 species. In the Thracian Sea, 150 species occurred at depths less than $200 \mathrm{~m}$, as were 81 in the bathymetric range of 200-500 m. A feature of the presence-dominance structure of the demersal fish communities in the study area was the occurrence of a relatively small group of species that were common and abundant. Fifteen species dominated depths <200 m $(83.81 \%$ of the overall catch), while $10(79.05 \%)$ dominated the upper slope in the Northern Aegean Sea. In the Thracian Sea 23 species were most abundant on the continental shelf $(89.02 \%$ of the overall catches), as were 12 at depths below $200 \mathrm{~m}$ (97.36\%). The remaining species made up a rather small proportion of the catches.

\section{Depth patterns in species composition}

Classification and ordination of the trawl catch data for each area in terms of species abundance revealed the existence of four groups associated with the continental shelf and the upper slope (Figs. 2a, 3a). Groups I and II consisted entirely of samples taken from the shallow stations of the continental shelf $(<100 \mathrm{~m})$ in the Northern Aegean and Thracian seas respectively, while deeper stations on the shelf for each area (100-200 m) were subsequently classified in group III. All stations from the upper slope for each area were classified in group IV. Dendrograms indicated a high degree of similarity between samples corresponding to each group (Table 1), suggesting well-defined spatial differences in species composition for each area. Furthermore, the MDS stress values were $<0.09$ in all cases verifying that the plots adequately represented the segregation of samples between groups (Figs. 2b, 3b). There did not appear to be any significant pattern of seasonal variation in composition of the catches for any of the station-groups resulting from this analysis.

A relatively small number of species contributed most to the similarity of each group and area, but their relative abundances varied between adjacent groups (i.e. groups I-II, groups III-IV; Table 1). Examination of the species that dominated in each group and contributed highly to the similarity indicates that most of the species presented a wide distribution range, implying that species differences between each group are quantitative rather than qualitative. Commercially important species were dominant in the shallowest zone (group I, $<30 \mathrm{~m}$ ), while non-commercial species predominated at depths below $200 \mathrm{~m}$. At intermediate depths (30-200 $\mathrm{m}$ ) almost $50 \%$ of the total catches consisted of noncommercially important fish species.

Analysis of similarity (ANOSIM) revealed that in each area the demersal fish assemblage of the shelf differed in structure from the assemblage of the upper slope (in all cases $\mathrm{R}>0.89, \mathrm{p}<0.001$ ). However, it did not detect any significant differences between seasonal samples, suggesting that 

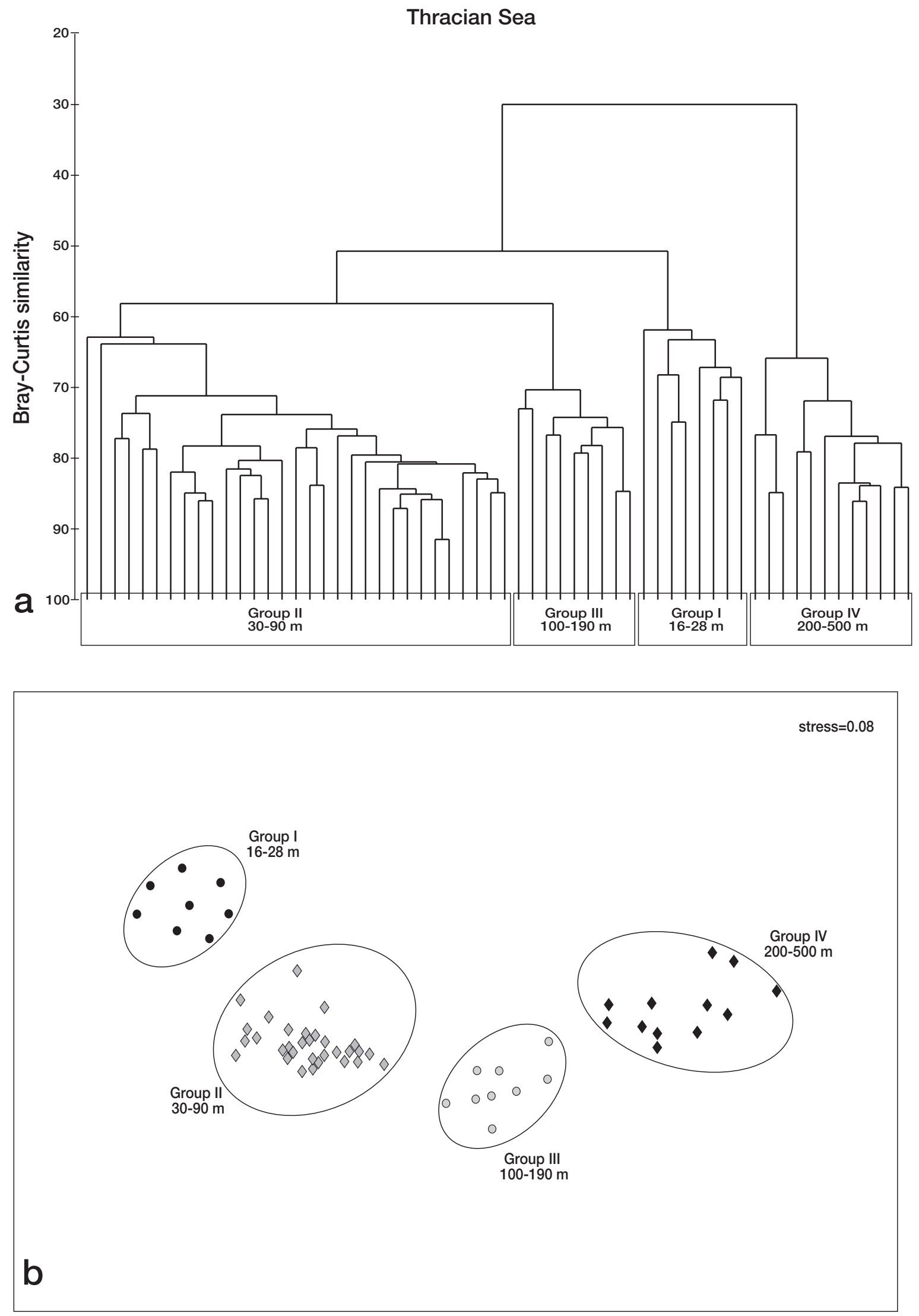

Fig. 2. - Classification (a) and ordination (b) of the sampling stations from the Thracian Sea based on species abundance. 

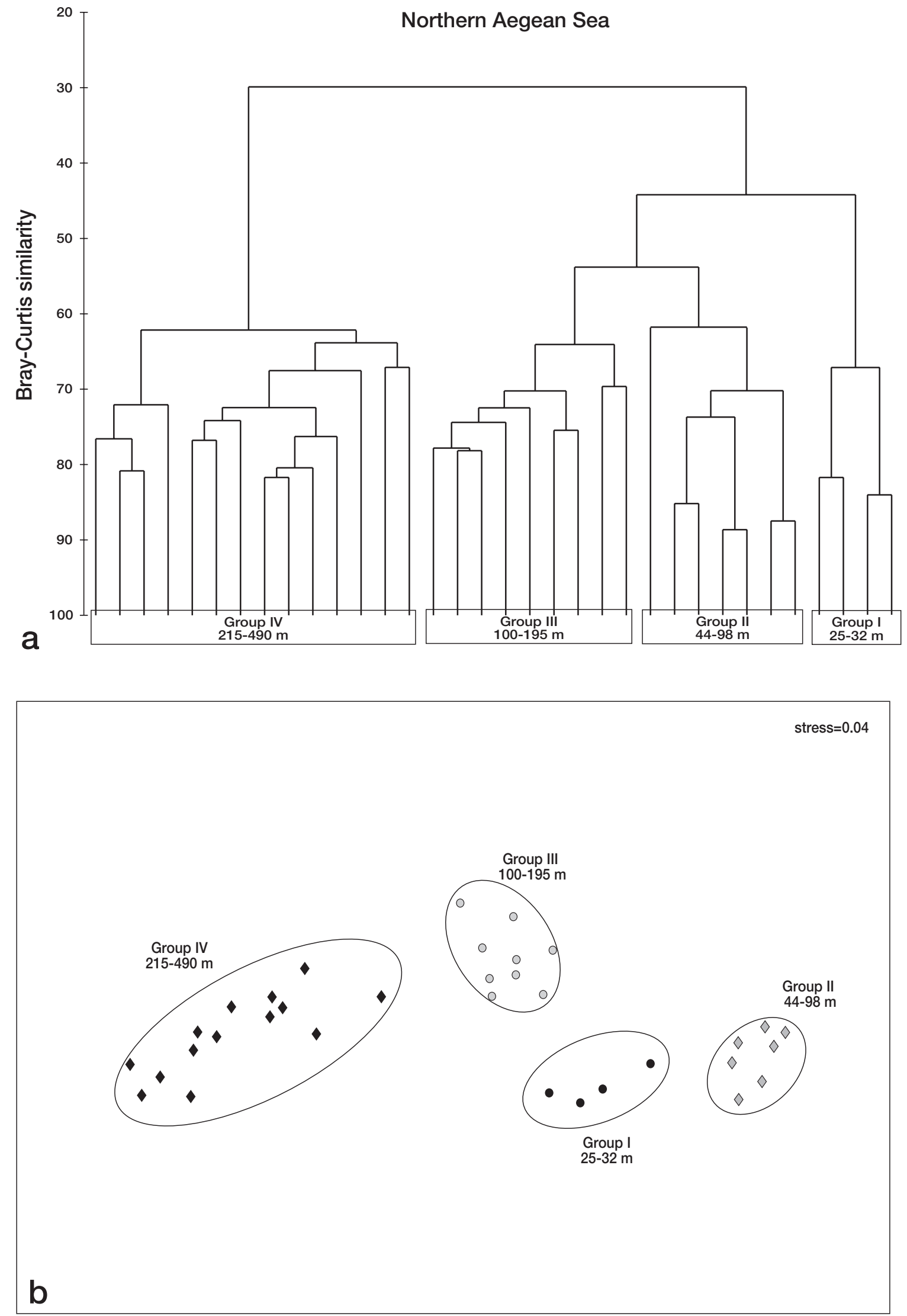

Fig. 3. - Classification (a) and ordination (b) of the sampling stations from the Northern Aegean Sea based on species abundance. 
TABLE 1. - Dominant fish species by area based on abundance rank for each station group identified by cluster analysis. Densities (\%N) are averaged over all samples in each group. \% Cum: average contribution to the similarity in each group. C indicates commercially important species.

\begin{tabular}{|c|c|c|c|c|c|c|c|}
\hline \multicolumn{3}{|c|}{$\begin{array}{l}\text { Group I (25-32 m) } \\
\text { average similarity: } 72.7 \mathrm{SD}: 4.8\end{array}$} & Nor & \multicolumn{2}{|c|}{$\begin{array}{l}\text { Group II (44-98 m) } \\
\text { average similarity: } 72.5 \text { SD: } 5.3\end{array}$} & $\%$ Cum. & \\
\hline Mullus barbatus & 62.32 & 8.68 & $\mathrm{C}$ & Merluccius merluccius & 6.88 & 9.93 & $\mathrm{C}$ \\
\hline Serranus hepatus & 7.08 & 15.87 & & Trachurus trachurus & 7.99 & 14.27 & $\mathrm{C}$ \\
\hline Spicara flexuosa & 3.50 & 22.52 & & Trisopterus minutus capelanus & 7.25 & 22.70 & $\mathrm{C}$ \\
\hline Pagellus erythrinus & 6.42 & 27.82 & $\mathrm{C}$ & Mullus barbatus & 23.45 & 30.22 & $\mathrm{C}$ \\
\hline Pagellus acarne & 0.84 & 32.45 & & Citharus linguatula & 7.94 & 33.67 & $\mathrm{C}$ \\
\hline Trachurus mediterraneus & 3.59 & 36.62 & $\mathrm{C}$ & Arnoglossus laterna & 2.31 & 39.94 & $\mathrm{C}$ \\
\hline Boops boops & 0.39 & 40.50 & $\mathrm{C}$ & Spicara flexuosa & 7.34 & 42.86 & \\
\hline Merluccius merluccius & 2.65 & 43.77 & $\mathrm{C}$ & Serranus hepatus & 11.72 & 45.63 & \\
\hline Serranus cabrilla & 0.28 & 46.99 & & Lesueurigobius friesii & 1.15 & 48.20 & \\
\hline Citharus linguatula & 0.11 & 49.95 & $\mathrm{C}$ & Lepidotrigla cavillone & 1.97 & 50.48 & \\
\hline Arnoglossus laterna & 1.12 & 52.87 & $\mathrm{C}$ & Cepola rubescens & 1.29 & 52.66 & \\
\hline Cepola rubescens & 0.32 & 55.76 & & Lophius budegassa & 0.77 & 54.81 & $\mathrm{C}$ \\
\hline Gobius niger & 0.11 & 58.36 & & Deltentosteus quadrimaculatus & 0.54 & 56.97 & \\
\hline Diplodus annularis & 4.58 & 60.92 & & Gaidropsarus sp. & 0.31 & 59.02 & \\
\hline Lepidotrigla cavillone & 0.01 & 63.15 & & Callionymus maculatus & 0.97 & 60.94 & \\
\hline Raja miraletus & 0.02 & 65.37 & $\mathrm{C}$ & Zeus faber & 0.17 & 62.82 & $\mathrm{C}$ \\
\hline Uranoscopus scaber & 0.16 & 67.45 & $\mathrm{C}$ & Symphurus ligulatus & 0.30 & 64.69 & \\
\hline Trigloporus lastoviza & 0.01 & 69.40 & $\mathrm{C}$ & Pagellus erythrinus & 1.23 & 66.42 & $\mathrm{C}$ \\
\hline \multirow[t]{2}{*}{ Mullus surmuletus } & 0.01 & 71.32 & $\mathrm{C}$ & Trachurus mediterraneus & 0.73 & 68.13 & $\mathrm{C}$ \\
\hline & & & & Trigla lyra & 0.47 & 69.75 & $\mathrm{C}$ \\
\hline \multicolumn{3}{|c|}{$\begin{array}{l}\text { Group III (100-195 m) } \\
\text { average similarity: } 69.2 \text { SD: } 6.2\end{array}$} & & \multicolumn{2}{|c|}{$\begin{array}{l}\text { Group IV (215-490 m) } \\
\text { average similarity: } 63.8 \mathrm{SD}: 5.9\end{array}$} & & \\
\hline Argentina sphyraena & 16.55 & 10.90 & & Gadiculus argenteus & 28.72 & 7.06 & \\
\hline Mullus barbatus & 6.07 & 18.15 & $\mathrm{C}$ & Lepidorhombus boscii & 5.71 & 13.43 & $\mathrm{C}$ \\
\hline Lepidotrigla cavillone & 5.99 & 25.35 & & Coelorhynchus coelorhynchus & 6.72 & 19.68 & \\
\hline Trachurus trachurus & 7.73 & 32.45 & $\mathrm{C}$ & Hymenocephalus italicus & 9.29 & 25.56 & \\
\hline Merluccius merluccius & 9.06 & 36.08 & $\mathrm{C}$ & Micromesistius poutassou & 12.58 & 31.40 & $\mathrm{C}$ \\
\hline Capros aper & 10.44 & 38.75 & & Merluccius merluccius & 2.68 & 36.05 & $\mathrm{C}$ \\
\hline Scyliorhinus canicula & 4.70 & 41.20 & & Argentina sphyraena & 8.22 & 40.66 & \\
\hline Trigla lyra & 2.06 & 43.65 & $\mathrm{C}$ & Phycis blennoides & 0.87 & 45.22 & $\mathrm{C}$ \\
\hline Aspitrigla cuculus & 2.37 & 46.10 & $\mathrm{C}$ & Trigla lyra & 1.12 & 49.71 & $\mathrm{C}$ \\
\hline Trisopterus minutus capelanus & 3.81 & 48.48 & $\mathrm{C}$ & Lophius budegassa & 0.50 & 53.67 & $\mathrm{C}$ \\
\hline Serranus hepatus & 2.60 & 50.75 & & Molva dipterygia macrophthalma & 0.53 & 57.45 & \\
\hline Raja clavata & 0.47 & 52.84 & $\mathrm{C}$ & Scyliorhinus canicula & 1.58 & 61.14 & \\
\hline Lophius budegassa & 0.69 & 54.90 & $\mathrm{C}$ & Peristedion cataphractum & 0.19 & 64.31 & \\
\hline Lepidotrigla dieuzeidei & 1.19 & 56.79 & & Capros aper & 0.41 & 67.39 & \\
\hline Citharus linguatula & 1.89 & 58.66 & $\mathrm{C}$ & Galeus melastomus & 0.41 & 69.50 & $\mathrm{C}$ \\
\hline Mullus surmuletus & 1.63 & 60.50 & $\mathrm{C}$ & Raja clavata & 0.22 & 71.56 & $\mathrm{C}$ \\
\hline Arnoglossus laterna & 0.49 & 62.34 & $\mathrm{C}$ & Chlorophthalmus agassizi & 1.43 & 73.37 & \\
\hline Eutrigla gurnardus & 0.15 & 64.05 & $\mathrm{C}$ & & & & \\
\hline Callionymus maculatus & 0.34 & 65.71 & & & & & \\
\hline Raja miraletus & 0.16 & 67.37 & $\mathrm{C}$ & & & & \\
\hline Lepidorhombus boscii & 2.38 & 69.01 & $\mathrm{C}$ & & & & \\
\hline Trachurus mediterraneus & 0.47 & 70.64 & $\mathrm{C}$ & & & & \\
\hline
\end{tabular}

the abundance, distribution and association patterns of the species remained the same in time, for each area under study.

\section{Community dominance}

Differentiation between station-groups in each area was evident by the graphical descriptors $(k-$ dominance curves), for numerical abundance (Fig. 4). Stations corresponding to groups II and III revealed more diversified and less dominated communities than those from the upper slope (group IV). The shallowest stations (group I) had an inter- mediate position in the Thracian Sea, while the curves were steeper and more elevated for group IV, suggesting that depths below $200 \mathrm{~m}$ were dominated by fewer species. The apparently high dominance curve for the shallowest stations (group I) of the North Aegean Sea reflects the dominance of Mullus barbatus, corresponding to the $62 \%$ of the total catch. Pairwise $k$-dominance curve comparisons between groups were significant in both areas, while the pairwise $\mathrm{R}$ values, which give an absolute measure of how separated the groups are, in all cases were $>0.75$, suggesting that the groups were well separated (Table 2). 
TABLE 1 (Cont.). - Dominant fish species by area based on abundance rank for each station group identified by cluster analysis. Densities (\% $\mathrm{N}$ ) are averaged over all samples in each group. \% Cum: average contribution to the similarity in each group. C indicates commercially important species.

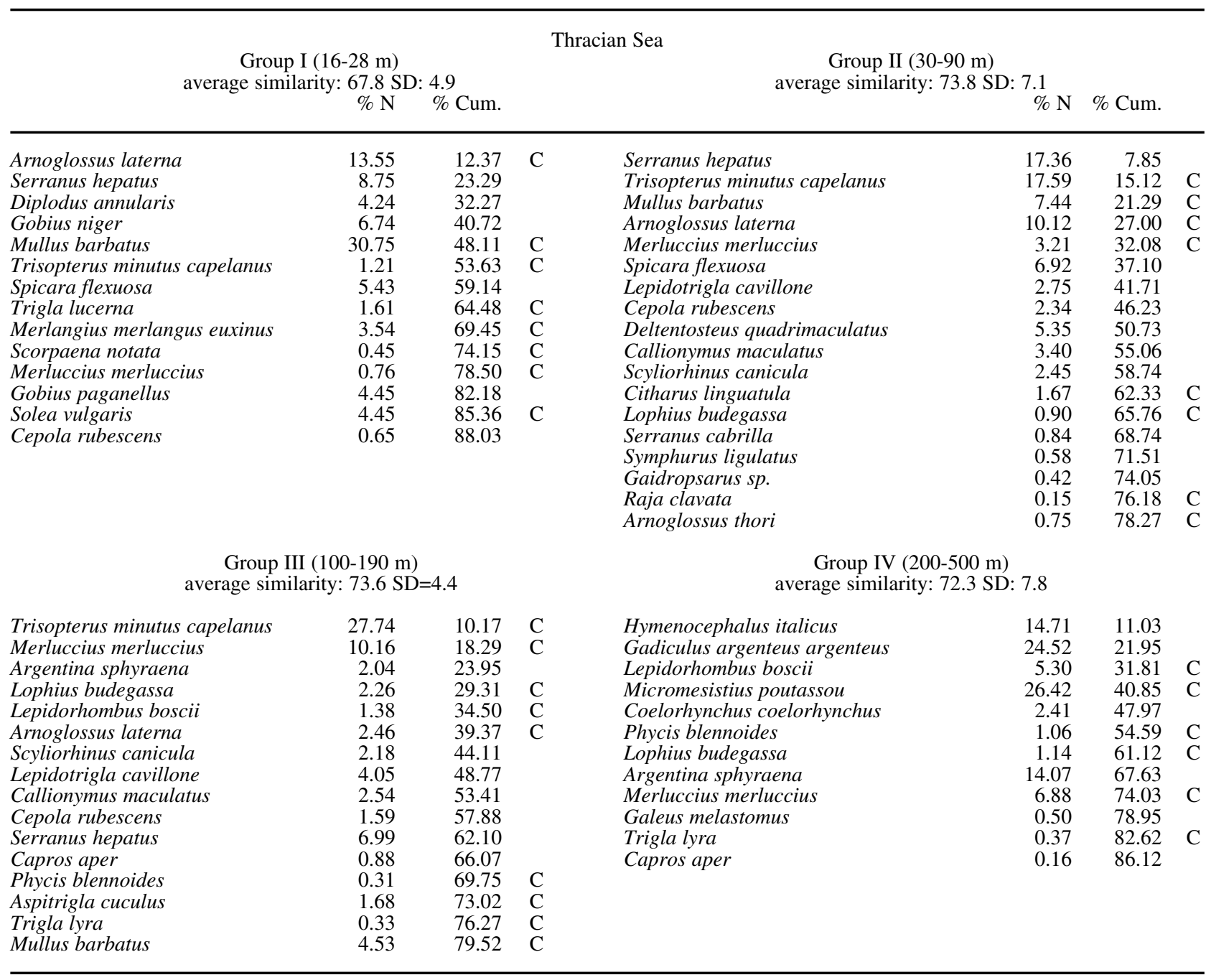
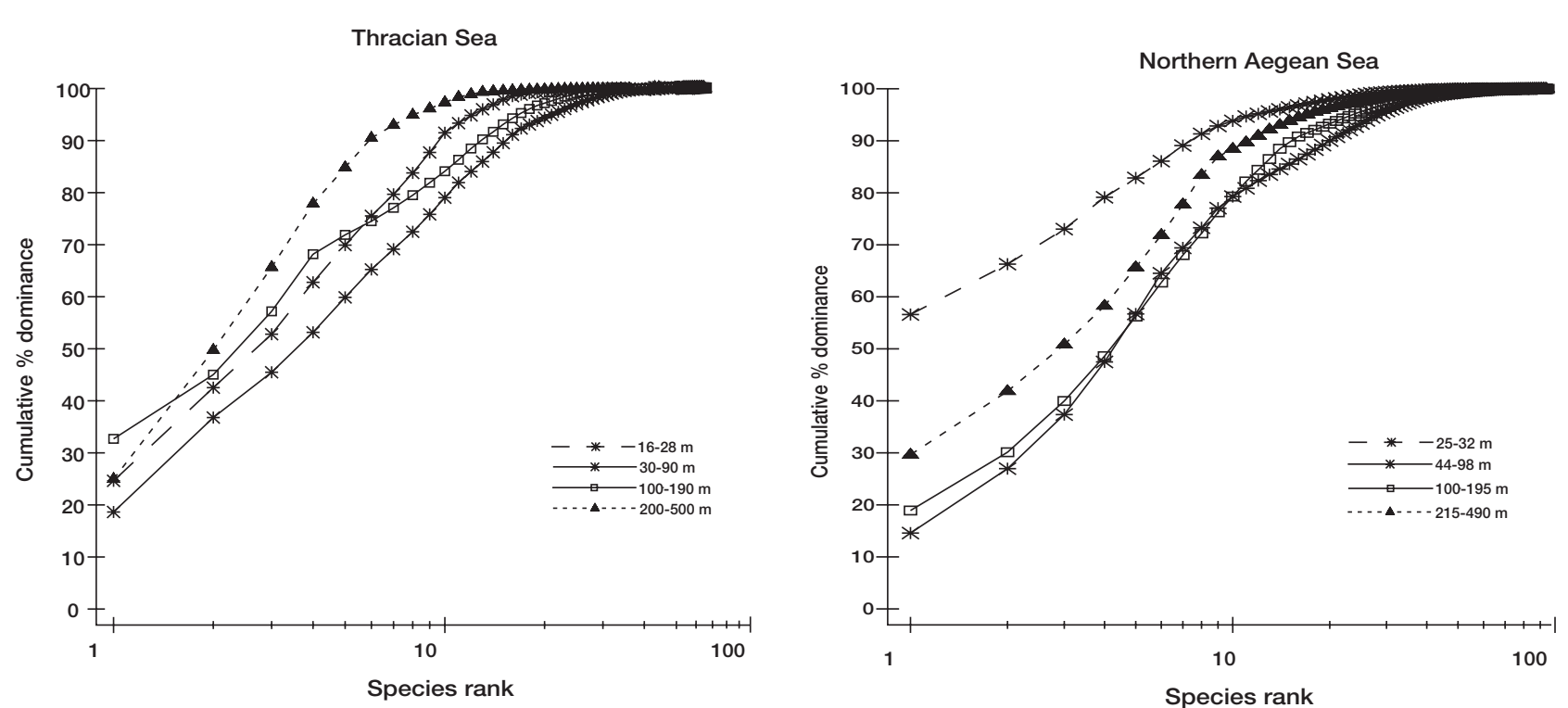

Fig. 4. - Comparison of $k$-dominance curves for the demersal fish communities between the four station-groups from the Northern Aegean and Thracian seas. 
TABLE 2. - Results of ANOSIM tests (R values) on the $k$-dominance curve data by area and depth group. In all cases $\mathrm{P}<0.001$

\begin{tabular}{|c|c|c|c|c|c|c|}
\hline \multirow[b]{2}{*}{ Groups } & \multicolumn{3}{|c|}{ Northern Aegean Sea } & \multicolumn{3}{|c|}{ Thracian Sea } \\
\hline & II & III & IV & II & III & IV \\
\hline I & 0.879 & 0.899 & 0.995 & 0.807 & 0.892 & 1.000 \\
\hline II & & 0.966 & 0.831 & & 1.000 & 0.872 \\
\hline III & & & 1.000 & & & 1.000 \\
\hline
\end{tabular}

\section{Patterns in abundance and species diversity with depth}

Significant differences in mean species abundance and diversity indices existed between the four depth zones for each area (Table 3 ). The highest values of these parameters were found in samples from the continental shelf (30-100 m, group II) and decreased significantly for those from the upper slope. The reverse was true for dominance that increased significantly with depth with maximal values at depths $>200 \mathrm{~m}$, except for the Northern Aegean Sea, which was dominated by $M$. barbatus at shallow depths (25-32 m). However, ecological parameters appeared to be more or less uniform at depths between 30-195 m (i.e., groups II and III), since differences were not significant with a Tukey HSD test.

\section{DISCUSSION}

Four distinctive demersal fish assemblages were clearly associated with the topography of the study areas. The three continental shelf assemblages exhibit greater abundance and contain species of larger size and commercial interest such as: Merluccius merluccius, Mullus barbatus, M. surmuletus, Pagellus erythrinus, and Trisopterus minutus capelanus. The upper slope assemblage is characterized by the predominance of species like Gadiculus argenteus, Micromesistius poutassou, Argentina sphyraena, Hymenocephalus italicus, Coelorhynchus coelorhynchus and Nezumia sclrorhynchus, which are small and not commercially important. The main determining feature associated with the structure of the demersal fish assemblages is depth, as it reflects the changes from continental shelf to continental slope. However, other bottom and oceanographic characteristics play a role, at least for structuring assemblages on the continental shelf between the two areas.

Several factors appear to contribute to this geographical differentiation. These include the gradient in eutrophy, fresh/brackish water runoff, temperature and salinity differences along a NNW to SSE axis, and differences in the extent and the bottom type of the continental shelf. Similarly, in other studies covering wide geographical areas differentiated assemblages, associated in general with environmental variability, were described (Bianchi, 1991, 1992a,b; Fariña et al., 1997b). Nevertheless, the most important quantitative boundary for all areas was located around $200 \mathrm{~m}$, a depth separating the species of the continental shelf from those of the upper slope extending down to $500 \mathrm{~m}$. These results are in agreement with the findings of Snelgrove and Haedrich (1985), who stated that deep assemblages tend to have a much broader depth range than do

TABLE 3. - Ecological parameters by area and depth zone and summary of statistical tests for the demersal fish communities in the North Aegean Sea

Northern Aegean Sea

Depth zones Depth (m) Abundance Afish h$\left.^{-1}\right) \quad$ Number of species (S) Richness (d) Diversity (H') Evenness (J') Dominance (D)

\begin{tabular}{|c|c|c|c|c|c|c|c|}
\hline 1 & $32.0(25-32)$ & $4.16( \pm 0.1)$ & $28.3( \pm 1.92)$ & $2.86( \pm 0.23)$ & $1.42( \pm 0.12)$ & $0.42( \pm 0.04)$ & $0.43( \pm 0.03)$ \\
\hline 2 & $67.6(44-98)$ & $3.19( \pm 0.7)$ & $29.7( \pm 0.55)$ & $3.89( \pm 0.07)$ & $2.21( \pm 0.03)$ & $0.66( \pm 0.01)$ & $0.22( \pm 0.02)$ \\
\hline 3 & $140.1(100-195)$ & $3.21( \pm 0.3)$ & $27.7( \pm 1.05)$ & $3.63( \pm 0.12)$ & $2.07( \pm 0.06)$ & $0.63( \pm 0.02)$ & $0.18( \pm 0.01)$ \\
\hline 4 & $359.1(215-490)$ & $3.23( \pm 0.4)$ & $24.7( \pm 0.59)$ & $3.19( \pm 0.07)$ & $1.92( \pm 0.04)$ & $0.61( \pm 0.01)$ & $0.24( \pm 0.01)$ \\
\hline $\mathrm{F}_{(3,211)}^{2}$ & & 19.81 & 12.59 & 21.01 & 21.38 & 15.23 & 18.58 \\
\hline
\end{tabular}

Thracian Sea

Depth zones Depth (m) Abundance ${ }^{1}\left(\right.$ fish h$\left.^{-1}\right) \quad$ Number of species (S) Richness (d) Diversity (H') Evenness (J') Dominance (D)

\begin{tabular}{|c|c|c|c|c|c|c|c|}
\hline 1 & $22.5(16-28)$ & $3.63( \pm 0.7)$ & $25.3( \pm 1.38)$ & $2.86( \pm 0.17)$ & $1.87( \pm 0.08)$ & $0.59( \pm 0.02)$ & $0.27( \pm 0.02)$ \\
\hline 2 & $57.3(30-90)$ & $3.36( \pm 0.3)$ & $32.7( \pm 0.54)$ & $4.26( \pm 0.10)$ & $2.31( \pm 0.05)$ & $0.67( \pm 0.01)$ & $0.19( \pm 0.01)$ \\
\hline 3 & $122.1(100-190)$ & $3.24( \pm 0.4)$ & $32.8( \pm 0.82)$ & $4.10( \pm 0.07)$ & $2.23( \pm 0.03)$ & $0.64( \pm 0.01)$ & $0.19( \pm 0.01)$ \\
\hline 4 & $303.4(200-500)$ & $3.12( \pm 0.5)$ & $25.3( \pm 0.90)$ & $3.21( \pm 0.11)$ & $1.76( \pm 0.05)$ & $0.55( \pm 0.01)$ & $0.30( \pm 0.02)$ \\
\hline $\mathrm{F}^{2}{ }_{(3,280)}$ & & 7.36 & 23.63 & 32.82 & 27.46 & 14.13 & 14.49 \\
\hline
\end{tabular}

\footnotetext{
${ }^{1}$ Mean and SE were calculated using $\log (\mathrm{x}+1)$-transformed data.

${ }^{2}$ In all cases $\mathrm{P}<0.001$
} 
shallow assemblages. At this depth species richness, abundance and biomass decline markedly. Below $200 \mathrm{~m}$, some factors of the benthic environment were remarkably stable. Sediment structure consisted of a dominant silt-clay fraction and temperature above these sediments was constant. This may be the major reason for the high degree of similarity among the species composition of the upper slope in the Northern Aegean and Thracian seas. However, it should also be mentioned that although trawling activity in Greek waters extends to depths down to $500 \mathrm{~m}$, trawlers operate more intensively in the fishing grounds of the continental shelf.

Shifts in the abundance and occurrence of demersal fish species were associated with a depth gradient, even though the species were found over relatively broad depth ranges in each of the study areas. Abundances of species varied significantly with depth, but whenever the depth ranges of these species overlapped, the depth of maximum abundance changed. Brown (1984) suggested that for ecologically similar species, those that attain the highest local population densities also tend to occur in a greater proportion of sampling sites and tend to have a wider spatial distribution. Hecker (1990) concluded that the changes in species composition between different megafaunal assemblages are due to the substitution of the dominant and subdominant species throughout the depth gradient by a continuous faunistic turnover. Other studies have also found depth-related trends in megabenthic faunas distribution, but patterns of depth gradients may be either zonation (Abelló et al., 1988; Cartes and Sardá, 1993; Fariña et al., 1997a) or a continuous replacement of species (Haedrich et al., 1980; Snelgrove and Haedrich, 1985; Fariña et al., 1997b; Moranta et al., 1998).

The observed pattern of gradual species replacement along the depth gradient is primarily based on the ontogenetic habitat shifts for some of the species and indicates that habitat selection may be based on the interaction between density-dependent food resources and density-independent environmental factors. Fish in the inshore zone tend to undertake an ontogenetic migration into deeper waters (Macpherson and Duarte, 1991; Warburton and Blaber, 1992; Blaber et al., 1995). Caddy (1993) hypothesized an offshore movement of older fish in several demersal species (e.g., sea breams, common pandora, mullets, etc.), possibly contributing to the continuing good recruitment in many areas, as well as to stock recovery. The preponderance of the positive size-depth relationships in fish species may reflect a funda- mental aspect of fish life history (Cushing, 1975). The occurrence of smaller, younger individuals in shallower water and the movement towards deeper waters during ontogeny must involve a substantial advantage. It has been suggested that, by migrating to deeper waters, the adults could benefit from a reduced basal metabolic rate and increased life expectancy at lower temperature (Macpherson and Duarte, 1991).

Overall in the Greek seas 447 fish species belonging to 129 families have been reported (Papaconstantinou, 1988). Thus, the number of species recorded in the present study represents $38.5 \%$ of the total marine ichthyofauna in Greece. In general, species composition is similar to that reported in other studies from the Mediterranean, but some differences in the relative abundance and dominance of several species become apparent between the different areas (Fariña et al., 1997b; D'Onghia et al., 1998; Moranta et al., 1998; Ungaro et al., 1998). However, species composition differs over the areas and depths examined. High species richness and diversity characterized the continental shelf, but both variables decreased markedly with depth, while the reverse was true for species dominance. On the other hand, evenness did not change with depth, indicating little variability in the numerical codominance of species over the depth range examined. The disparities in these general trends for group I in each area may be attributable to the more variable environments in shallow coastal waters. The $k$-dominance analysis suggested that the spatial trend in diversity and dominance was a strong feature of the species assemblages under study, with dominance being the highest in group IV. Bianchi et al. (2000), who investigated whether changes in diversity and dominance could be related to fishing, concluded that the largest changes in diversity appeared to be due to changes in evenness or species richness, or both, often leading to an increase in diversity in response to heavy exploitation.

Community classifications should take temporal persistence into account. However, most studies of the zonation of demersal fish fail to consider temporal variation (Markle et al., 1988; Bianchi, 1991; 1992a,b; Moranta et al., 1998). In the present study, multivariate analyses did not detect any annual changes in the overall structure of the assemblages in each area. Furthermore, results suggest that changes in the assemblages' composition are weakly associated with seasonal changes. Therefore the demersal fish communities persisted over time and 
species rankings also remained constant, at least for our cruise dates. The apparent lack of seasonality has also been observed in other studies on fish assemblages (i.e. May and Blaber, 1989; Wright, 1989; Wantiez et al., 1996; Ungaro et al., 1998). Nonetheless, it should be noted that in order to detect temporal changes in groundfish assemblages, the length of the time series must be considered. Some inferences are possible only with long term data series. For example, in a study lasting from 1978 to 1991 on the Newfoundland continental shelf, Gomes et al. (1995) found that even though stock sizes had been declining steadily, changes in species assemblages could be detected only after several years of decline.

Regardless of the actual balance between biotic and abiotic factors in determining the demersal fish assemblages, the occurrence of relatively homogeneous areas of species composition has relevance to multispecies management. Mixed catches within the area of a given assemblage offer a redundancy in terms of species composition and relative abundances. Such information can be of value in dealing with by-catch and provide general guidelines for overall rational planning and management (Gomes et al., 1992).

The overall structure of the demersal fish communities studied here stresses once more the multispecies character of the Greek fisheries and Mediterranean fisheries in general. Management should take into account this diversity, since fishing activities in these areas are not species selective. Despite the enforcement of regulations for demersal and inshore fisheries in Greek waters (i.e. closed seasons and areas, limited issue of licenses, minimum legal landing size and mesh size regulations), the fishing effort in the Northern Aegean and Thracian seas is very high. Besides, although closed seasons and areas can be effective in restricting fishing mortality on particular life stages, such a measure may lead to an increase in mortality beyond that prior to the application of the measure if catches are high outside the closed seasons and areas. Additionally we can consider the possibility that in certain periods, effort may be directed in an alternative and major way towards one or another target species, depending on the level of catch obtained at that time and market demands and in consequence of the respective strength of recruitment in each species (Oliver, 1993; Goñi et al., 1999).

Studies in other areas, based on extended time series during which major increases in fishing effort took place, indicate that fishing led to a decrease in catches and to increases in non-commercial species (Overholtz and Tyler, 1985; Rothschild, 1992). Furthermore, there is evidence that the size structure of demersal fish communities is affected by fishing. The overall trend is one of a reduction in large fish and a relative increase in small fish (Bianchi et al., 2000; Zwanenburg, 2000). In the present study, the fish assemblages under consideration have suffered a long history of fishery exploitation. Therefore overfishing has affected the population structures and densities of the demersal fish communities, at least at depths up to $200 \mathrm{~m}$, where most of the fishing activity is focused. It is possible that the organization of the demersal fish assemblages analysed are determined to a great extent by an unidirectional trend induced by fishing, bottom topography and oceanographic features of the study areas.

\section{ACKNOWLEDGEMENTS}

The authors thank all those involved in demersal trawl surveys in the Northern Aegean and Thracian seas, carried out by the Fisheries Department of the National Centre for Marine Research, for their valuable help. This work was partially supported by the EU, DG XIV under the Contract No MA-1-90, and the Greek General Secretariat for Research and Technology.

\section{REFERENCES}

Abelló, P., F.J. Valladares and A. Castellón. - 1988. Analysis of the structure of decapod crustacean assemblages off the Catalan coast (North-West Mediterranean). Mar. Biol., 98: 39-49.

Bianchi, G. - 1991. Demersal assemblages of the continental shelf and slope edge between the gulf of Tehuantepec (Mexico) and the gulf of Papagayo (Costa Rica). Mar. Ecol. Prog. Ser., 73: 121-140.

Bianchi, G. - 1992a. Study of the demersal assemblages of the continental shelf and upper slope off Congo and Gabon, based on the trawl surveys of the RV 'Dr Fridtjof Nansen'. Mar. Ecol. Prog. Ser., 85: 9-23.

Bianchi, G. - 1992b. Demersal assemblages of the continental shelf and upper slope of Angola. Mar. Ecol. Prog Ser., 85: 101-120.

Bianchi, G., H. Gislason, K. Graham, L. Hill, X. Jin, K. Koranteng, S. Manickchand -Heileman, I. Payá, K. Sainsbury, F. Sánchez and K. Zwanenburg. - 2000. Impact of fishing on size composition and diversity of demersal fish communities. ICES J. Mar. Sci., 57: 558-571.

Blaber, S.J., D.T. Brewer, and J.P. Salini. - 1995. Fish communities and the nursery role of the shallow inshore waters of a tropical bay in the Gulf of Carpentaria, Australia. Estuar. Coast. shelf Sci., 40: 177-193.

Brown, J.H. - 1984. On the relationship between abundance and distribution of species. Am. Nat., 124: 255-279.

Caddy, J.F. - 1993. Some future perspectives for assessment and management of Mediterranean fisheries. Sci. Mar., 57: 121-130.

Carney, R.S., R.L. Haedrich and G.T. Rowe. - 1983. Zonation of 
fauna in the deep sea. In: G.T. Rowe (ed.), Deep-Sea Biology, The Sea, 8, pp. 371-398. Wiley-Interscience, New York.

Cartes, J.E., and F. Sardà. - 1993. Zonation of deep-sea decapod fauna in the Catalan Sea (Western Mediterranean). Mar. Ecol. Prog. Ser., 94: 27-34.

Cartes, J.E., J.B. Company and F. Maynou. - 1994. Deep-water decapod crustacean communities in the Northwestern Mediterranean: influence of submarine canyons and season. Mar. Biol., 120: 221-229.

Clarke, K.L. - 1993. Non-parametric multivariate analyses of change in community structure. Aust. J. Ecol. 18: 117-143.

Cushing, D.H. - 1975. Marine Ecology and Fisheries. Cambridge University Press. Cambridge.

D’Onghia G., G. Tursi, P. Maiorano, A. Matarrese and M. Panza. 1998. Demersal fish assemblages from the bathyal grounds of the Ionian Sea (middle-eastern Mediterranean). Ital. J. Zool., 65(Suppl): 287-192.

Farinã, A.C., J. Freire and E. González-Gurriarán. - 1997a. Megabenthic decapod crustacean assemblages on the Galician continental shelf and upper slope (north-west Spain). Mar. Biol., 127: 419-434.

Farinã, A.C., J. Freire and E. González-Gurriarán. - 1997b. Demersal fish assemblages in the Galician continental shelf and upper slope (NW Spain): spatial structure and long term changes. Estuar. Coast. shelf Sci., 44: 435-454.

Field J.G., K.R. Clarke and R.M. Warwick. - 1982. A practical strategy for analysis of multispecies distribution patterns. Mar. Ecol. Prog. Ser., 8: 37-52.

Fujita, T., T. Inada and Y. Ishito. - 1995. Depth-gradient structure of the demersal fish community on the continental shelf and upper slope off Sendai Bay, Japan. Mar. Ecol. Prog. Ser., 118: 13-23.

García, C.B., L. Orlando Duarte and D. von Schiller. - 1998. Demersal fish assemblages of the Gulf of Salamanca, Colombia (southern Caribbean Sea). Mar. Ecol. Prog. Ser., 174: 13-25.

Gislason, H., M. Sinclair, K. Sainsbury and R. O'Boyle. - 2000. Symposium overview: incorporating ecosystem objectives within fisheries management. ICES J. Mar. Sci., 57: 468-475.

Gomes, M.C., R.L. Haedrich and J.C. Rice. - 1992. Biogeograhy of groundfish assemblages on the Grand Bank. J. Northw. Atl. Fish. Sci., 14: 13-27.

Gomes, M.C., Haedrich, R.L. and M.G. Villagarcia. - 1995. Spatial and temporal changes in the groundfish assemblages on the Northeast Newfoundland/Labrador Shelf, Northwest Atlantic, 1978-1991. Fish. Oceanog., 4: 85-101.

Goñi, R., Alvarez, F. and Adlerstein, S. - 1999. Application of generalized linear modelling to catch rate analysis of Western Mediterranean fisheries: the Castellón trawl fleet as a case study. Fish. Res., 42: 291-302.

Gordon, J.D.M., N.R. Merrett and R.L. Haedrich. - 1995. Environmental and biological aspects of slope dwelling fishes. In: A.G. Hopper (ed.), Deep water fisheries of the North Atlantic Ocean Slope. Kluwer, Dordrecht, pp. 1-30.

Haedrich, R.L. and S.M. Barnes. 1997. - Changes over time of the size structure in an exploited shelf fish community. Fish. Res., 31: 229-239.

Haedrich, R.L., G.T. Rowe and P.T. Polloni. - 1980. The megabenthic fauna in the deep sea south of New England, USA. Mar. Biol., 57: 165-179.

Hecker, B. 1990. - Variation in megafaunal assemblages on the continental margin south of New England. Deep-Sea Res., 37: 37-57.

Hurlbert, S.H. - 1978. The measurement of niche overlap and some relatives. Ecology, 59: 67-77.

Koslow, J.A. - 1993. Community structure in North Atlantic deepsea fishes. Prog. Oceanogr., 31: 321-338.

Krebs, C.J. - 1989. Ecological methodology. Harper and Row, New York.

Labropoulou M. and C. Papaconstantinou. - 2000. Community structure of deep-sea demersal fish in the North Aegean Sea (northeastern Mediterranean). Hydrobiologia, 440: 281-296.

Lambshead, P.J.D., H.M. Platt and K.M. Shaw. - 1983. The detection of differences among assemblages of marine benthic species based on an assessment of dominance and diversity. $J$. nat. Hist., 17: 859-874.
Macpherson, E. and C.M. Duarte. - 1991. Bathymetric trends in demersal fish size: is there a general relationship? Mar. Ecol. Prog. Ser., 71: 103-112.

Margalef, R. - 1968. Perspectives in ecological theory. University of Chicago Press, Chicago: Illinois.

Markle, D.F., M.J. Dadswell and R.G. Hallliday. - 1988. Demersal fish and decapod crustacean fauna of the upper continental slope off Nova Scotia from LaHave to St. Pierre Banks. Can. J. Zool., 66: 1952-1960.

May, J.L. and S.J.M. Blaber. - 1989. Benthic and pelagic fish biomass of the upper continental slope off eastern Tasmania. Mar. Biol., 101: 11-25.

Moranta, J., C. Stefanescu, E. Massuti, B. Morales-Nin and D. Lloris. - 1998. Fish community structure and depth-related trends on the continental slope of the Balearic Islands (Algerian basin, western Mediterranean). Mar. Ecol. Prog. Ser., 171: 247-259.

NSSG (National Statistical Service of Greece) Bulletins. - 19901994. Statistical Year Book. Athens, Greece.

Oliver, P. - 1993. Analysis of fluctuations observed in the trawl fleet landings of the Balearic Islands. Sci. Mar., 57: 219-227.

Overholtz, W.J. and A.V. Tyler. - 1985. Long-term changes of the demersal fish assemblages of Georges Bank. Fish. Bull., 83: 507-520.

Papaconstantinou, C. - 1988. Check-list of marine fishes of Greece. Fauna Graecia. National Centre for Marine Research and Hellenic Zoological Society. Athens

Papaconstantinou, C. and H. Farrugio. - 2000. Fisheries in the Mediterranean. Med. Mar. Sci., 1: 5-18.

Pielou, E.C. 1966. - The measurement of diversity in differences types of biological collections. J. theor. Biol., 13: 131-144.

Rothschild, B.J. 1992. - Multispecies interactions on George Bank. ICES Mar. Sci. Symp., 195: 418-423.

Sainsbury, K.J., Campell, R.A., Lindholm, R. and Whitelaw A.W - 1997. Experimental management of an Australian multispecies fishery: examining the possibility of trawl induced habitat modification. In: E.K. Pikitch, D.D. Huppert and M.P. Sissenwine (eds.), Global trends: Fisheries Management. American Fisheries Society, Bethesda, Maryland, USA. pp. 197-212.

Sardà, F., J.E. Cartes and J.B. Company. - 1994. Spatio-temporal variations in megabenthos abundance in three different habitats of the Catalan deep-sea (Western Mediterranean). Mar. Biol., 120: 211-219.

Smale, M.J., B.A. Roel, A. Badenhorst and J.G. Field. - 1993 Analysis of the demersal community of fish and cephalopods on the Aguilas Bank, South Africa. J. Fish Biol., 43 (Suppl. A): 169-191

Snelgrove, P.V.R. and R.L. Haedrich. - 1985. Structure of the deep demersal fish fauna off Newfoundland. Mar. Ecol. Prog. Ser., 27: 99-107.

Sokal, R.R. and F.J. Rohlf. - 1981. Biometry: The principles and practice of statistics in biological research. Freeman. San Francisco.

Ungaro N., C.A. Marano, A. Vlora and M. Martino. - 1998. Spacetime variations of demersal fish assemblages in the south-western Adriatic sea. Vie Milieu, 48(3): 191-201.

Wantiez, L., M. Harmelin-Vivien and M. Kulbicki. - 1996. Spatial and temporal variation in a soft-bottom fish assemblage in $\mathrm{St}$ Vincent Bay, New Caledonia. Mar. Biol., 125: 801-812.

Warwick, R.M. - 1986. A new method for detecting pollution effects on marine benthic communities. Mar. Biol., 92: 557562 .

Warburton, K. and S.J.M. Blaber. - 1992. Patterns of recruitment and resource use in a shallow-water fish assemblage in Moreton Bay, Queensland. Mar. Ecol. Prog. Ser., 90:113-126

Wright, J.M. - 1989. Daily variation and seasonal consistency in the fish assemblage of the non-estuarine Sulaibikhat Bay, Kuwait. Mar. Biol., 1021: 135-142.

Zar, J.H.. - 1984. Biostatistical analysis. Prentice-Hall, Englewood Cliffs.

Zwanenburg, K.C.T. - 2000. The effects of fishing on demersal fish communities of the Scotian Shelf. ICES J. Mar. Sci., 57: 503-509. 